\title{
En mann med feber og magesmerter
}

Feber og magesmerter uten klinisk sikker diagnose er en vanlig årsak til innleggelse i sykehus. Dersom kliniske symptomer og blodprøver indikerer at det kan være en bakteriell infeksjon, er det, etter at man har tatt blodkultur, naturlig å starte med antibiotika raskt. Av og til kan imidlertid symptomene skyldes noe helt annet.

Se kommentar side 1832 og kunnskapsprøve på www.tidsskriftet.no/quiz

\section{Kathrine Aglen Seeberg} seek@uus.no

Bodil Hammerstad Selbekk

Gastromedisinsk avdeling

Oslo universitetsykehus, Ullevål 0407 Oslo

En 34 år gammel mann ble innlagt i gastrokirurgisk avdeling med spørsmål om kolecystitt. Med unntak av forbigående prostatittplager noen år tidligere hadde han vært frisk. Han brukte ingen faste medisiner og hadde ingen kjent allergi.

Mannen hadde fått akutt innsettende magesmerter og feber dagen før innleggelsen. Natten før hadde han hatt flere episoder med frysninger. Innleggelsesdagen fikk han et erytematøst, ikke-kløende utslett på brystet. Ved undersøkelse på legevakten var han lett febril $\left(38,2^{\circ} \mathrm{C}\right)$, palpasjonsøm under høyre costalbue og $i$ epigastriet. Urinstiks var negativ og CRP-nivået $120 \mathrm{mg} / \mathrm{l} 10-10$ $m g / l)$.

Ved ankomst til sykehuset var klinisk status uendret, og det var ingen palpable lymfeknuter. Han hadde et rødprikkete utslett på overkroppen. Blodtrykket var 129/72 $\mathrm{mm} \mathrm{Hg}$ og pulsen 85 slag per minutt. Urinstiks viste 1+ på leukocytter og protein, negativ nitritt.

Flere differensialdiagnoser ble vurdert, blant annet kolecystitt, ulcus ventriculi, ulcus duodeni og pankreatitt. Tilstedeværelse av hudutslett og feber gjorde det imidlertid nærliggende å tro at dette kunne være en infeksjon med abdominalt utgangspunkt. Differensialdiagnostisk kunne utslettet skyldes en allergisk reaksjon. Bildediagnostikk ville kunne bidra til en avklaring før man eventuelt startet antibiotikabehandling.

CT abdomen viste kun reaktive forandringer i fettvev mesenterialt samt multiple og for- størrede lymfeknuter i dette området (fig 1). Blodprøvene viste $S R 35 \mathrm{~mm}(2-10 \mathrm{~mm})$, CRP $145 \mathrm{mg} / \mathrm{l}$, hemoglobin $13,6 \mathrm{~g} / 100 \mathrm{ml}$ $(13,4-17,0 \mathrm{~g} / 100 \mathrm{ml})$, leukocytter 7,7 · $10 \% / \mathrm{l}$ (3,5-10:10\%/l), ASAT $125 \mathrm{U} / \mathrm{l}(15-45 \mathrm{U} / \mathrm{l})$, ALAT 136 U/l (10-70 U/l), GT 79 U/l (10-80 U/l), ALP 96 U/l (35-105 U/l). På grunnlag av kliniske funn og blodprøver ble det startet med antibiotika i form av piperacillin-tazobactam.

Dagen etter viste blodprøver tegn til begynnende kolestase. GT var $174 \mathrm{U} / \mathrm{l}, \mathrm{ALP}$ $192 \mathrm{U} / \mathrm{l}$ og bilirubin $73 \mu \mathrm{mol} / \mathrm{l}(5-25 \mu \mathrm{mol} / \mathrm{l})$. Transaminaser var ytterligere økt (ASAT 150 U/l, ALAT 212 U/l), og INR-nivået var 1,3. Kontroll av infeksjonmarkører viste fortsatt normale leukocytter, men lymfocytter på $0,1 \cdot 10^{9} / \mathrm{l}\left(1,5-4 \cdot 10^{\%} / \mathrm{l}\right)$. CRP-nivået hadde økt til $241 \mathrm{mg} / \mathrm{l}$. Øvrige prøver var normale. Pasienten var febril $\left(39,2^{\circ} \mathrm{C}\right)$ og fortsatt palpasjonsøm i abdomen.

Kolecystitt ble utelukket og pasienten overflyttet til medisinsk avdeling. Det var imidlertid fortsatt ikke avklart hva slags sykdomstilstand han hadde. Kompletterende prøver på Epstein-Barr-virus, cytomegalovirus, viral hepatitt og hiv og prøver på immunologisk hepatitt ble tatt. Da lymfocyttnivået var $0,1 \cdot 10^{9} / 1$, ble det også gjort et blodutstryk. Det kom frem at pasienten en uke tidligere hadde vært på hyttetur i fjellet, derfor ble det tatt serologisk prøve på Hantavirus.

Etter to døgn med antibiotika (piperacillintazobactam) var pasienten fremdeles febril. Han hadde liten effekt av antipyretika, var ikterisk på sclera og i huden, men hadde mindre vondt $i$ magen. Han var kvalm og hadde kastet opp et par ganger. Det makuløse, konfluerende utslettet hadde bredt seg ut på truncus, rygg og underekstremiteter, spesielt $i$ lyske og perinealt (fig 2). Det var negativt resultat av hurtigtest på Hantavirus. Blodutstryk viste aniso-poikilocytose og trombocytose, men ingen sikkert patologis- ke celler. Det ble supplert med magnetisk resonanskolangiopankreatografi (MRCP), som ikke viste galleblærekonkrement eller gallegangsstein, men galleblæren ble beskrevet som ødematøs. I tillegg ble det også angitt noe ødem i buken med litt væske omkring begge nyrer (fig 3).

Etter tre døgn utviklet pasienten palmoplantart erytem (fig 4), hovne føtter opp til ankelnivå og konjunktival blødning på begge øynene (fig 5). Det tilkom også papillær hypertrofi på tungen. Feberen vedvarte.

Differensialdiagnostisk kunne et viralt eller bakteriologisk agens forårsake pasientens sykdomsbilde. Man tok derfor serologiske prøver for tularemi, leptospirose, chlamy-

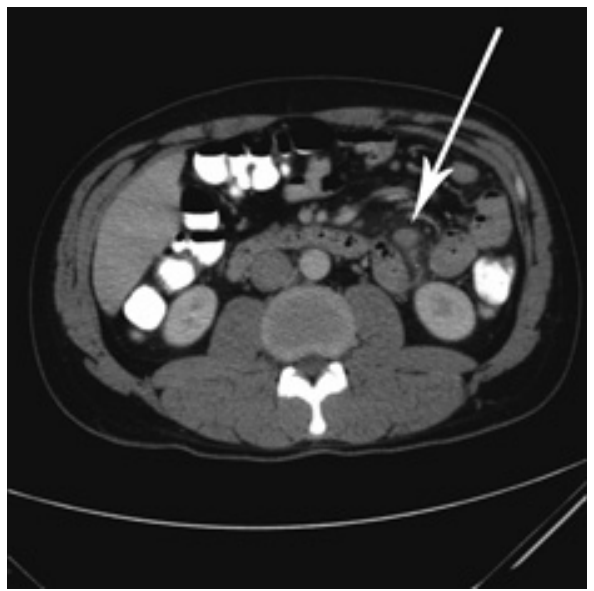

Figur 1 CT abdomen tatt med intravenøs kontrast viste reaktive forandringer med multiple forstørrede lymfeknuter (pil) i mesenterialt fettvev

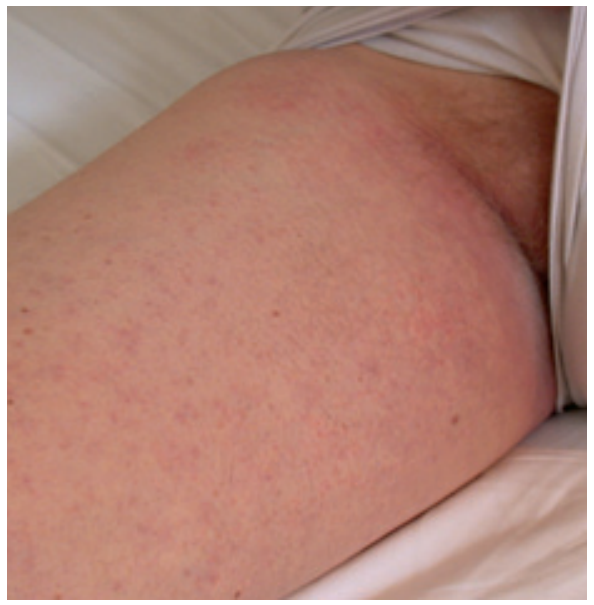

Figur 2 Utbredt makuløst konfluerende utslett ilyske 
dia, mycoplasma pneumonia, parvovirus og Coxackie-virus.

Antibiotikaregimet ble endret fra piperacillin-tazobactam til ciprofloksacin og doksysyklin med mistanke om tularemi (orofaryngeal variant og uten forstørrede lymfeglandler på hals, men mesenterialt) (1).

Pasientens sykdomsbilde kunne også være forenlig med en immunologisk tilstand, på tross av forhøyet CRP-nivå (262 $\mathrm{mg} / \mathrm{l})$. For å utelukke vaskulitt eller bindevevssykdom ble det rekvirert ANCA, ANAELISA, anti-GBM, AMA, SMA, LKM1, IgM og IgG. Ved gjennomgang av litteraturen og etter diskusjon kolleger imellom kom vi frem til at sykdomsbildet kunne likne Kawasakis sykdom (2).

Dette er akutt systemisk vaskulitt som primært affiserer små barn under fem år. For å kunne stille diagnosen kreves det at pasienten har feber i mer enn fem dager og oppfyller fire av følgende fem kriterier (3):

- Cervikal lymfadenopati

- Oralmukosale forandringer («jordbærtunge», såre, sprukne lepper, injisert pharynx)

- Polymorft hudtslett

- Bilateral konjunktival injeksjon

- Ekstremitetsforandringer med palmoplantart erytem og påfølgende deskvamasjon av huden

Selv om sykdommen primært affiserer barn, er tilstanden også beskrevet hos voksne. Hos voksne er det i tillegg til ovennevnte kriterier hyppigere rapportert om patologiske leverprøver, uspesifisert lymfadenopati og artralgi (4).

Pasienten hadde på dette tidspunkt hatt vedvarende feber i fem dager, makuløst utslett, palmoplantart erytem, bilateral lokal konjunktival injeksjon og «jordbærtunge». Radiologiske undersøkelser viste mesenterial lymfadenitt og ødematøs galleblære. Blodprøver viste kolestasemønster.
Intravenøs behandling med immunglobulin og platehemmer peroralt ble vurdert for å forebygge komplikasjoner. Koronare aneurismer er en alvorlig komplikasjon ved ubehandlet Kawasakis sykdom (2). Ekkokardiografisk undersøkelse viste normale forhold. Alle immunologiske prøver var negative. Siden diagnosen ikke sikkert kunne verifiseres, var det svært usikkert om pasienten burde ha behandling med intravenøs immunglobulin. Mangel på erfaring med liknende sykdomstilfeller samt kostnadene ved en slik behandling var faktorer av betydning for å avvente. Biopsi av karvegg fra affisert område i abdomen kunne kanskje ha bekreftet diagnosen. Pasientens kliniske tilstand var på dette tidspunktet stabil, og vi mente derfor at et slikt inngrep, uten noen garanti for å få histologisk diagnose, ikke ville ha behandlingsmessig konsekvens.

Det ble derimot gjort en pediatrisk vurdering av pasienten. Det ble konkludert med inkomplett Kawasakis sykdom (3), siden tre av de fem diagnostiske kriterier var til stede - palmoplantart erytem, bilateral konjunktival injeksjon og polymorft hudutslett. På dette tidspunkt hadde pasienten mindre grad av papillær hypertrofi. Etter ytterligere diskusjon med kardiologer, pediatere, hudlege og revmatolog valgte vi å avstå fra behandling med intravenøs immunglobulin.

Pasienten ble skrevet ut etter 12 dager $i$ sykehus. Han hadde da fått ciprofloksacin $i$ seks dager. Ved utskrivning ble det gjort ekkokardiografisk kontroll, og det var fortsatt ikke tegn til hyperekkogene koronarkar eller aneurisme. Blodprøver viste nå CRP 23 $\mathrm{mg} / \mathrm{l}$, hemoglobin $11,4 \mathrm{~g} / 100 \mathrm{ml}$ og lymfocytter $0,7 \cdot 10^{9} /$, det var normaliserte transaminaser og bilirubin samt stigende trombocyttnivå (987 . 10\%/l. Han fikk forskrevet Albyl E $75 \mathrm{mg}$ daglig på grunn av trombocytose. I tillegg fortsatte han med ciprofloksacin peroralt i ytterligere fem dager.

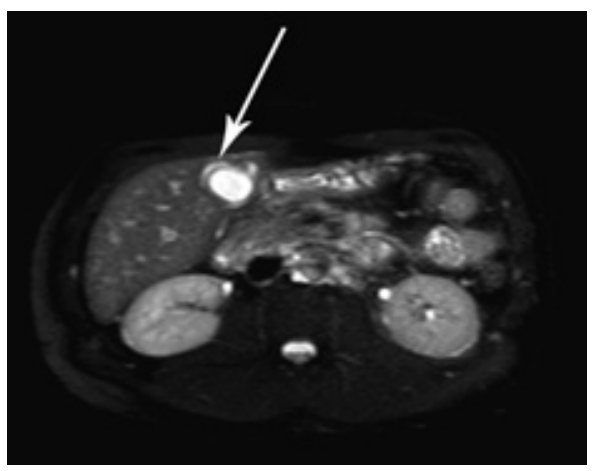

Figur 3 Magnetisk resonanskolangiopankreatografi (MRCP) viste ingen tegn til kolestase, men ga mistanke om lettgradig kolecystitt Imarkert galleblærevegg og lette ødemforandringer i galleblæreseng) (pil)

Pasienten ble senere fulgt opp med en poliklinisk kontroll tre uker etter utskrivning. Blodprøvekontroll viste da SR $29 \mathrm{~mm}$, hemoglobin $12,2 \mathrm{~g} / 100 \mathrm{ml}$, trombocytter 247. 10\%/l, ASAT $32 \mathrm{U} / \mathrm{l}$ og ALAT $46 \mathrm{U} / \mathrm{l}$. Han fortalte at han etter utskrivningen hadde hatt leddsmerter, spesielt i knærne, og deskvamasjon på håndflater og føtter. Plagene hadde vart $i$ en ukes tid, de var derfor gått tilbake ved den polikliniske kontrollen.

Pasientens sykdomsforløp ble oppfattet som forårsaket av Kawasakis sykdom (ramme 1).

\section{Diskusjon}

Kawasakis sykdom er en vaskulitt som primært forekommer hos barn under fem år. Sykdommen er den vanligste årsaken til ervervet hjertesykdom hos barn i den industrialiserte verden (5). Etiologien er ukjent, men man har holdepunkter for å tro at tilstanden er postinfeksiøs. Hypersensitivitet eller forstyrrelser i immunforsvaret, sannsynligvis utløst av en infeksjon, kan indusere inflammasjon i mindre arterier $(3,6)$.

Sykdommen har en akutt fase som varer

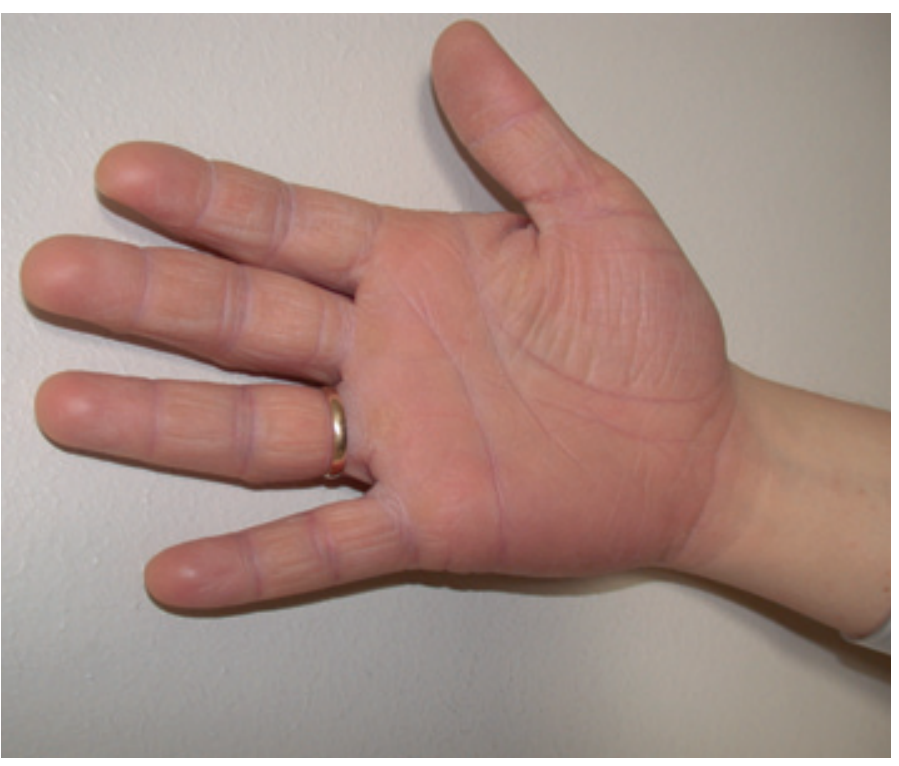

Figur 4 Pasienten utviklet etter tre døgn palmart erytem

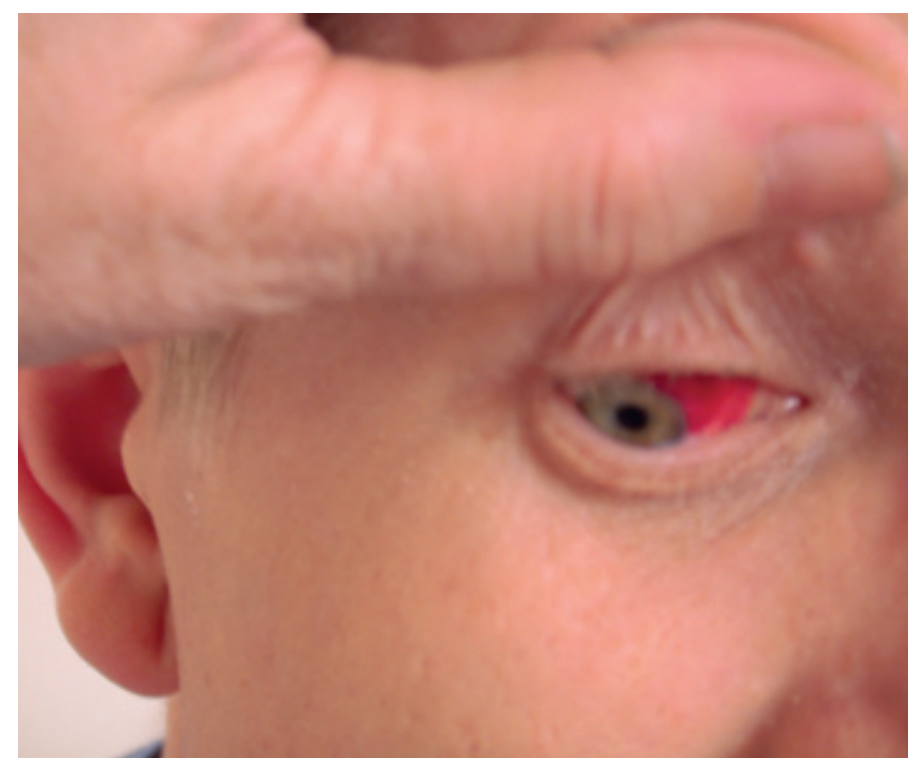

Figur 5 Markert konjunktival injeksjon/blødning i høyre øye 


\section{Ramme 1}

\section{Diagnostiske kriterier ved Kawasakis sykdom}

Feber i mer enn fem dager og tilstedeværelse av fire av følgende kriterier:

Cervikal lymfadenopati

Forandringer i oropharynx: såre, sprukne lepper; papillær hypertofi på tungen, injisert pharynx

Polymorft hudutslett

Bilateral konjunktival injeksjon

Ekstremitetsforandringer med rubor

og ødem med etter hvert deskvamasjon av hud på hender og føtter

7-14 dager og en subakutt fase på 10-20 dager (2). Ubehandlet sykdom tilheler vanligvis spontant etter fire til seks uker (7). Risikoen for komplikasjoner i form av koronart aneurisme er ved ubehandlet sykdom $20-25 \%$ hos barn og 5\% hos voksne (2). Målet med behandlingen er å dempe den akutte inflammasjonen og forebygge alvorlige kardiovaskulære komplikasjoner. Behandling med immunglobulin intravenøst er godt dokumentert hos barn. Standardbehandlingen i dag er én enkelt dose gammaglobulin $(2 \mathrm{~g} / \mathrm{kg})$ i akuttfasen, etterfulgt av en lav dose acetylsalisylsyre over et par måneder. Argumenter for ikke å igangsette behandling er kostnadene ved bruk av medisinen, risiko for transfusjonsreaksjon og det at vaksinering med levende virus må utsettes $\mathrm{i}$ inntil seks måneder (7).

Kawasakis sykdom er en sjelden tilstand hos voksne. Totalt er det beskrevet i underkant av 60 tilfeller i litteraturen (3). Av disse var ni personer hivpositive. I Europa er det registrert 25 tilfeller, de øvrige i USA (25 personer), i Asia (fem) og i Afrika (to). Disse pasientene hadde diagnosen Kawasakis sykdom (feber pluss fire av fem kliniske symptomer) eller inkomplett Kawasakis sykdom. I de rapporterte tilfellene hos voksne er det ofte adenopati og økte leververdier. I tillegg er trombocytose, icterus og artralgi hyppig forekommende i subakuttfasen (4). Det er også beskrevet tilfeller av Kawasakis sykdom med galleblærehydrops, anemi, forhøyet senkningsreaksjon og forhøyet CRPnivå, slik som hos vår pasient (3).

Av de 57 tilfellene som var rapportert frem til 2005 , hadde 18 pasienter fått intravenøs behandling med immunglobulin. Denne behandlingen ble gitt med bakgrunn i retningslinjer for barn, søk i litteraturen og andre publiserte artikler (3), da det ikke foreligger kunnskapsbasert behandling for voksne. Det er ikke rapportert om dødsfall hos voksne i forbindelse med sykdommen (2). Så langt er Kawasakis sykdom i Norge bare beskrevet hos barn (8). Aktuelle differensialdiagnoser hos voksne er toksisk sjokk-syndrom, hypersensitivitetsreaksjon på medikamenter og viral eller vektorbåren infeksjonssykdom.

Grunnlaget for å sette diagnosen Kawasakis sykdom hos vår pasient var kliniske funn, radiologiske undersøkelser, kliniskkjemiske prøver og komplett negativ bakteriell og viral agens- og antistoffpåvisning. Alle de immunologiske prøvene var også innenfor referanseområdet. Pasienten hadde i akuttfasen høy senkningsreaksjon og høyt CRP-nivå, lettgradig anemi, økning av transaminaser og tegn til kolestase. Radiologisk var det galleblærehydrops. I subakuttfasen utviklet han trombocytose. Det er ikke dokumentert hvor lenge behandling med lavdose acetylsalisylsyre bør kontinueres hos voksne. Med utgangspunkt i tidligere publiserte kasuistikker valgte vi en behand- lingsvarighet på to måneder med Albyl E 75 mg daglig (3).

Forekomsten av Kawasakis sykdom hos voksne er lav, og det har derfor ikke vært mulig å gjennomføre prospektive randomiserte studier for valg av behandling. Tilgjengelig litteratur om Kawasakis sykdom hos voksne er begrenset. Gjennomgang av litteraturen viser at behandlingsstrategiene er kunnskapsbasert medisin på laveste nivå (nivå 3). Det gir ikke noe grunnlag for å konkludere hvorvidt pasienter rutinemessig bør ha behandling med intravenøs immunglobulin.

Pasienten har gitt samtykke til at artikkelen blir publisert.

Oppgitte interessekonflikter: Ingen

\section{Litteratur}

1. Moxness MH, Bergh K. Tularemi som differensialdiagnose ved tumor colli. Tidsskr Nor Lægeforen 2006; 126: 1055-7.

2. Wolff AE, Hansen KE, Zakowski L et al. Acute Kawasaki disease: not just for kids. J Gen Intern Med 2007: 22: 681-4

3. Sève P, Stankovic K, Smail A et al. Adult Kawasaki disease: report of two cases and literature review. Semin Arthritis Rheum 2005; 34: 785-92.

4. Dauphin C, Motreff P. Souteyrand G et al. La maladie de Kawasaki est aussi une maladie de l'adulte. Arch Mal Coeur Vaiss 2007; 100: 439-47.

5. Hoffman TU, Paerregaard A. Kawasakis syndrom en infektionssygdom? Ugeskr Læger 2002; 164: 5934-6.

6. Hansen SK, Buhl MR. Kawasaki-syndrom hos en voksen. Ugeskr Læger 1998; 160: 1807-8.

7. Rozo JC, Jefferies JL, Eidem BW el al. Kawasaki disease in the adult: a case report and review of the literature. Tex Heart Inst J 2004: 31: 160-4.

8. Klevberg S, Farstad T, Perminow KV. Forekomst av Kawasakis sykdom. Tidsskr Nor Lægeforen 2004; 124: 1774-5.

Manuskriptet ble mottatt 16.3. 2009 og godkjent 25.2. 2010. Medisinsk redaktør Are Brean.

\section{Alvorlig immunreaksjon uten mikrober}

Kawasakis sykdom har ukjent årsak. En kraftig immunrespons genereres i personer som sannsynligvis er genetisk disponert for tilstanden. Sykdommen rammer først og fremst barn, men er beskrevet hos i alt 81 voksne (1). Immunresponsen er knyttet til vaskulitt i mellomstore arterier og gir symptomer fra en rekke organer. Det er først og fremst immunrespons og inflammasjon i koronararteriene som gir varig organaffeksjon i form av utvikling av aneurismer eller stenoser, med koronar iskemi som følge. Immunologisk er Kawasaksi sykdom interessant både med tanke på patofysiologien og med tanke på behandlingseffekten av intravenøst gammaglobulin.

Sykdommen er beskrevet som en reaksjon på en mikrobiell stimulering. Det har vært mange forslag på hvilke mikroorganismer som kan utløse Kawasakis sykdom, men ingen er vist å kunne utløse sykdommen. Det kan påvises inflammasjon i middels store arterier med antistoffer av IgM- og IgG-klasse som reagerer med antigener på endotelcellene. Det er også påvist IgA-produserende plasmaceller subendotelialt (2).

I akuttfasen er pasientenes symptomer dominert av feber, utslett, leveraffeksjon, lymfadenopati. Analyser av blodet viser forhøyet CRP-nivå, lavt albuminnivå, middels leukocytose og trombocytopeni. Bildet gjenspeiler aktivering av det medfødte immunforsvaret - med makrofagaktivering og produksjon av proinflammatoriske cytokiner slik som interleukin-1 (IL), IL-6, tumornekrosefaktor $\alpha$ og granulocytt-/monocyttkolonistimulerende faktor. Det spesifikke immunforsvaret igangsettes med aktivering av T-celler og B-celler som produserer antiendotelcelle-IgM og -IgG. Disse antistoffene kan aktivere komplement, og aktivering av komplement på endotelcelleoverfla- 